\title{
Eragrostis surreyana (Poaceae) an uncommon, habitat restricted new species from the Pilbara Bioregion of Western Australia
}

\author{
Kelly A. Shepherd and Malcolm E. Trudgen \\ Western Australian Herbarium, Department of Environment and Conservation, Science Division, \\ Locked Bag 104, Bentley Delivery Centre, Western Australia 6983, Australia \\ Author for correspondence: Kelly.Shepherd@dec.wa.gov.au
}

\begin{abstract}
Eragrostis surreyana K.A.Sheph. \& Trudgen sp. nov. is a diminutive annual lovegrass named for the late Surrey Jacobs (1946-2009). This species is restricted to seasonal wetland areas in the Pilbara Bioregion of Western Australia. Although it is quite widespread, E. surreyana is currently only known from five locations and it is likely it has suffered loss of populations through habitat degradation caused by sheep and cattle grazing. It is therefore considered to be a species of conservation concern. Eragrostis surreyana produces numerous culms and forms a small tussock. It is distinguished from related species by its flexuose rachilla, ovate lemmas and short hairs along the keel of each palea. A description, images and a map of the distribution of this new species is provided.
\end{abstract}

\section{Introduction}

The lovegrass genus Eragrostis Wolfis includes around 350 species world wide. Eragrostis has been revised for the Flora of Australia project (Palmer et al. 2005), a treatment that draws on the earlier work by Lazarides (1997). At that time there were 73 species recorded in Australia, of which 15 were considered to be weeds. Based on the current Western Australian Census there are 19 species of Eragrostis in the Pilbara Interim Biogeographic Regionalisation for Australia (IBRA) region, including two Priority Three conservation listed species (E.crateriformis Lazarides and E. lanicaulis Lazarides) and the two weeds ( ${ }^{\star} E$. pilosa (L.) P.Beauv. and ${ }^{\star} E$. xerophila Domin) (Western Australian Herbarium 1998+, Smith 2010).

The diminutive new species described herein as Eragrostis surreyana K.A.Sheph. \& Trudgen was first collected in 1978 during a vegetation survey of the Burrup Peninsula. In the subsequent report this taxon was named 'Eragrostis cf. basedowii' (Blackwell et al. 1978); however, the specimen was never lodged at the Western Australian Herbarium (PERTH). A subsequent survey of the Burrup some 24 years later resulted in the re-collection of this taxon, which was informally named Eragrostis sp. Mt Montagu (Trudgen \& Associates 2002). Examination of allied species at PERTH also identified a 
specimen that was collected from the eastern edge of the Robe River Catchment in 1996 (A.A. Mitchell PRP 1518), which had been determined as 'Eragrostis sp. nr cumingii' by Mike Lazarides. It is likely that the taxonomic status of this specimen could not be resolved at the time due to a lack of adequate corroborating specimens. Assessment of these collections and further specimens obtained during a field trip to the Burrup Peninsula in 2009 has confirmed this taxon as distinct.

Eragrostis surreyana is poorly known as it has only been recorded from four populations in the Chichester Range including Mt Montagu, south of Pannawonica and from a single location on the Burrup Peninsula. Based on current knowledge (PERTH collections and a private database of c. 6000 Pilbara Bioregion vegetation sites maintained by the second author) this species is believed to be very uncommon. Furthermore, as a species restricted to seasonal wetland areas, populations of E. surreyana may be threatened by the physical destruction of such habitats by livestock and the invasion of weeds. Species of the genus Cenchrus L. in particular pose a serious problem, as many are allelopathic and reach high densities in seasonal wetlands. Since E. surreyana is a species of conservation concern it was considered a priority to name.

There is also a single collection of a potentially new taxon phrase named E. sp. Mt Robinson (S. van Leeuwen 4109) from the Pilbara region at PERTH. While this taxon has been given a Priority One conservation status, its taxonomic status could not be resolved here due to a lack of adequate material.

\section{Methods}

Characters were measured from specimens lodged at the Western Australian Herbarium (PERTH) and from fresh material collected in the field.

As Eragrostis surreyana is a species of conservation concern exact localities of known populations have been withheld. A distribution map was produced using DIVA-GIS Version 5.2.0.2. (http://www.diva-gis.org/) and includes the Interim Biogeographic Regionalisation for Australia (IBRA) categories Version 6.1 (Department of the Environment, Water, Heritage and the Arts 2008) as modified on FloraBase.

\section{Taxonomy}

Eragrostis surreyana K.A.Sheph. \& Trudgen sp. nov.

Species insignis a speciebus notis bene distincta; habitu minore, spiculis compressis, rachillis flexuosis, lemmatibus ovatis, margine palearum pilis brevissimis ornato, statim dignoscenda.

Type: Western Australia, about $100 \mathrm{~km}$ N of Tom Price. A.A. Mitchell PRP 1518, 10 Sep 1996; holo. PERTH4995511; iso. CANB, DNA, K n.v.

Tufted annual 5-8 (-13) cm high. Culms erect to decumbent, 2.5-5 (-13) cm long. Leaves glabrous; ligule ciliolate, $0.2-0.35 \mathrm{~mm}$ long; blade loosely rolled, $16-35 \mathrm{~mm}$ long, 0.2-0.6 mm wide. Inflorescence terminal and axillary. Terminal panicles spiciform, 90-130 mm long, 5-12 $\mathrm{mm}$ wide; branches divided, entirely spikelet-bearing, 10-30 mm long. Spikelets often overtopped by leaf blades, linear-oblong, laterally compressed, $4.8-13 \mathrm{~mm}$ long, $1.1-3 \mathrm{~mm}$ wide; almost sessile or pedicel $0.1-0.3 \mathrm{~mm}$ long; rachilla flexuose, internodes $0.3-0.5 \mathrm{~mm}$ long; florets $8-30$ ( -33$)$, imbricate 
becoming loosely overlapping. Glumes persistent, deciduous at maturity, unequal, ovate, membranous; lower glume 1-2.2 mm long; upper glume $1.3-2.7 \mathrm{~mm}$ long. Lemma deciduous, glabrous, narrowly ovate, apex acute, often mucronate, $1.2-1.9 \mathrm{~mm}$ long, keel ribbed, glabrous or sometimes scabrous, nerves ribbed. Palea persistent, $2 / 3$ as long as lemma; body oblong to ovate, keel scabrous with small hairs $0.025-0.05 \mathrm{~mm}$ long. Anthers $0.2-0.3 \mathrm{~mm}$ long. Grain ovoid, laterally compressed, $0.35-0.5 \mathrm{~mm}$ long, $0.25-0.4 \mathrm{~mm}$ wide, pale brown. (Fig. $1 \mathrm{a}-\mathrm{e}$ )

Flowering. Fertile collections have been made from May to September.

Selected specimens examined: Western Australia: R. Butcher, K.A. Shepherd, J.A. Wege, S. van Leeuwen \& V. Long RB 1378, 27 May 2009 (CANB, PERTH); R. Butler RB02, 24 Jul 2009 (CANB, NSW, PERTH); V. Long MET «A 157, 27 Jun 2000, (AD, PERTH); K.A. Shepherd, R. Butcher, J.A. Wege, S. van Leeuwen \& V. Long KS 1229, 27 May 2009 (CANB, PERTH); M. Trudgen \& D. True MET 1026, 13 Aug 1991 (MEL, PERTH); M.S. Trudgen \& R. Butler RB03, 25 Jul 2009 (PERTH); M.S. Trudgen \& R. Butler RB04, 24 Jul 2009 (PERTH); C. van der Bergh 04R 128-16, 4 Jun 2009 (PERTH).

Distribution and habitat. Currently only known from the Pilbara IBRA region of the Eremaean Botanical Province (Fig. 2). Eragrostis surreyana is usually found in seasonally wet, shallow, grey alluvial soils over rock, with some from deeper soils in a seasonally wet creek line. Most collections have been made from streams, with one from a seasonal seepage area on a gentle slope near the base of the Chichester escarpment. Associated species include a sedgeland - tussock grassland with Cyperus vaginatus R.Br., Schoenus falcatus R.Br., Fimbristylis rara R.Br., Stemodia grossa Benth., Pluchea rubelliflora (F.Muell.) B.L.Rob. and Stylidium fluminense F.L.Erickson \& J.H.Willis.

Conservation status. As Eragrostis surreyana is currently only known from five isolated populations and may be vulnerable to threats of habitat loss through disturbance and weed invasion, it has been recently listed as Priority Three under the Conservation Codes for Western Australian Flora (Smith 2010). Priority Three taxa are regarded as being poorly known and have been recorded from several populations, some of which are not thought to be under immediate threat. This species is under consideration for listing as Declared Rare Flora but is in urgent need of further survey. As this taxon is poorly known it would be listed in the 'Data Deficient' category under the IUCN Red List Categories and Criteria (IUCN Standards and Petitions Subcommittee 2010).

Etymology. This species is named for the late Surrey Jacobs (1946-2009), who made significant contributions to Australian systematic research throughout his distinguished career on a wide range of plant groups including native grasses.

Common name. Surrey's Lovegrass

Affinities. This tufted annual species of Eragrostis has a number of distinguishing features such as diminutive size; numerous culms; laterally compressed spikelets, which are usually overtopped by the leaf blades; flexuose rachilla; ovate lemma and short hairs only $0.025-0.05 \mathrm{~mm}$ long along the keels of the palea. These characters separate this new species from the two species that appear to be most closely allied to it: E. cumingii Steud. and E. basedowii Jedwabn.

Eragrostis surreyana is distinct from the widespread and common E. cumingii Steud. as this species is usually taller with fewer culms and has inflorescences extending beyond the leaf blades; straight rachilla; ovate or elliptic to orbicular lemma that are gibbous on the back and thickened hairs $0.1-0.4 \mathrm{~mm}$ long on the palea keel (Fig. $1 \mathrm{f} \mathrm{\&} \mathrm{g).}$ 

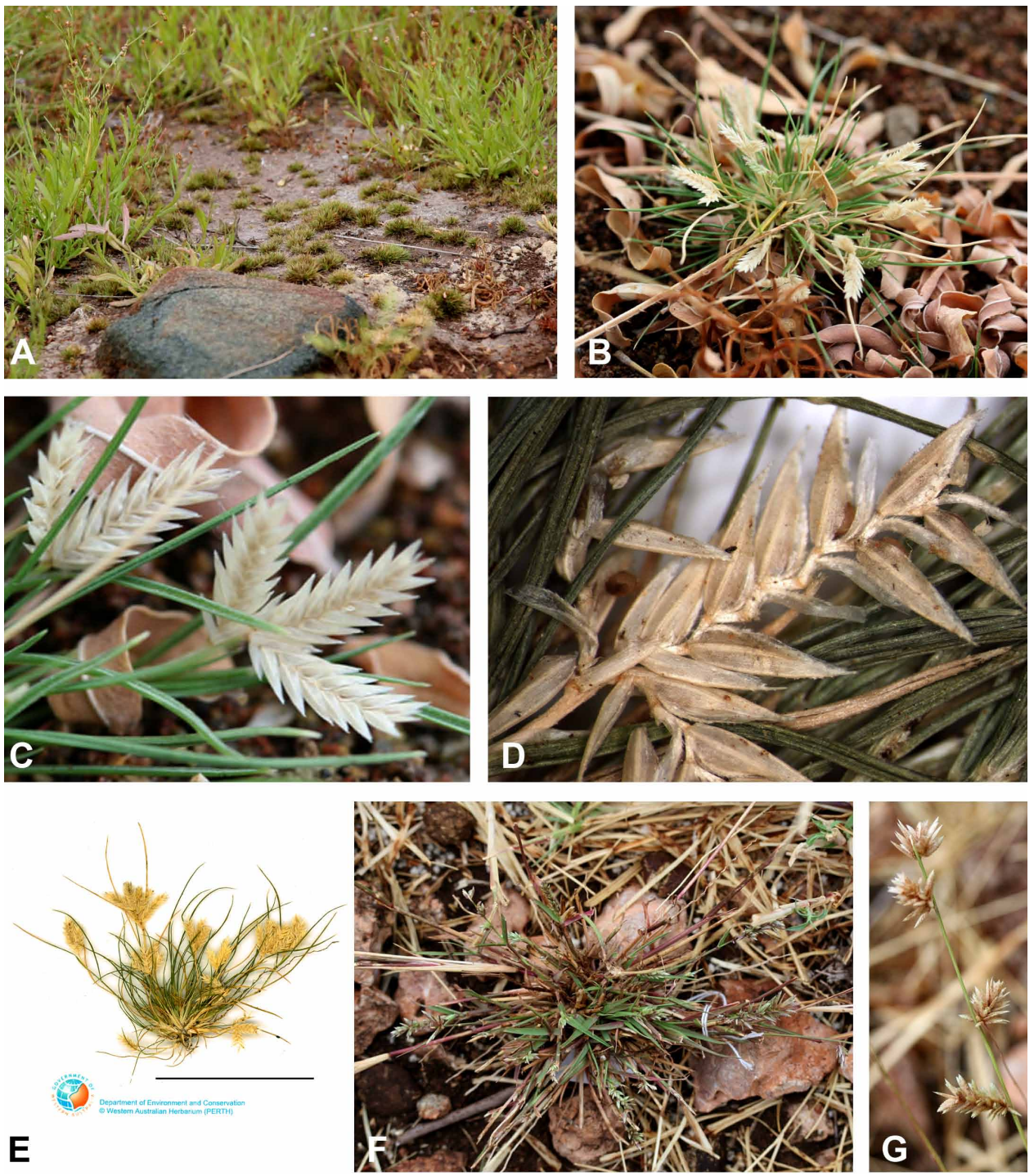

E

Fig. 1. Eragrostis surreyana. a, small tufted plants (in centre of the image); b, habit; c, \& d, spikelets; e, scan of a specimen (K.A. Shepherd et al. KS 1229, PERTH 08079439); Eragrostis cumingii. f, habit; g, inflorescence. Photographs by K.A. Shepherd. Scale bar $=30 \mathrm{~mm}$. 
While Eragrostis basedowii Jedwabn. is not currently known in Western Australia, this small tufted annual also has narrow acute lemmas that are $>2.5 \mathrm{~mm}$ long, similar to E. surreyana. Features that distinguish E. basedowii from this new species are its flat or only loosely rolled leaf blades 30-100(-260) mm long; straight rachilla; granulartextured (in dried material) lemmas and rigid hairs $0.25-0.5 \mathrm{~mm}$ long on the palea keel.

Notes. Eragrostis cumingii, which is extremely common in the Pilbara Bioregion, grows in somewhat similar habitats to E. surreyana but on deeper soils. The two species may be ecologically separated as E. cumingii is likely to establish earlier and experience a longer growing season, while E. surreyana will only appear in shallow soils around wet seepages once they begin to dry out later in the season.

\section{Acknowledgments}

This research was partially funded by Woodside Energy through their commitment to Offset Three within the Pluto LNG Development Offsets program and also through a specific nature conservation project grant (2009-2010) within the Nature Conservation Service (formerly labelled as the Biodiversity Conservation Initiative). Paul Hoffman (Biota Environmental Sciences) kindly provided collections. Jo Palmer and Mike Lazarides are gratefully acknowledged for taking the time to examine material sent to CANB and for supplying very helpful comments on an earlier draft of the description and Ryonen Butcher for comments on the manuscript. Dave Albrecht and John Jessop also confirmed this species as distinct from Eragrostis basedowii. Paul Wilson graciously corrected the Latin diagnosis.

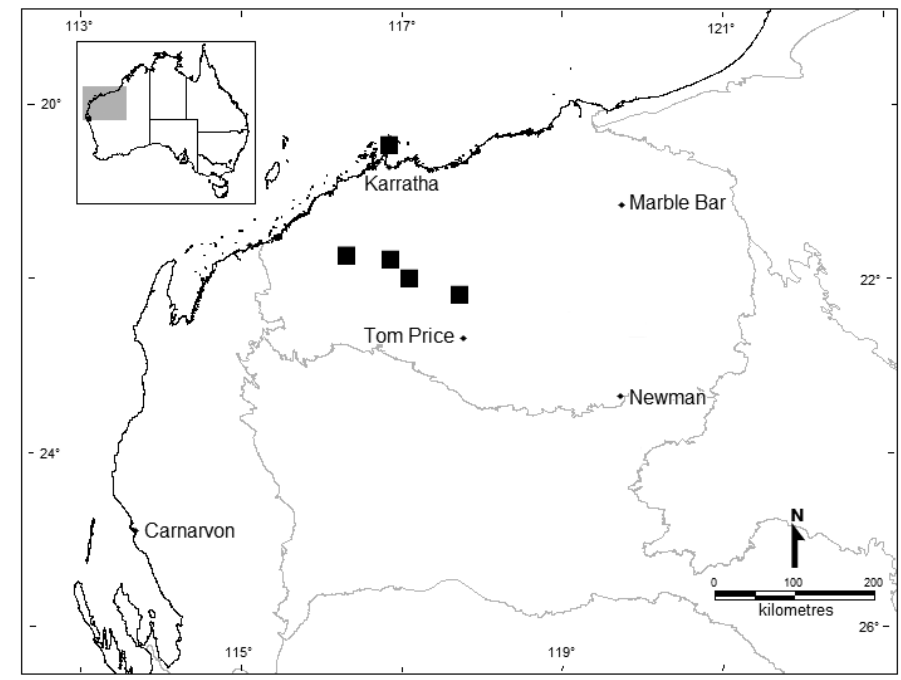

Fig. 2. Distribution of Eragrostis surreyana in Western Australia with IBRA regions Version 6.1 in grey (Department of the Environment, Water, Heritage and the Arts 2008). 


\section{References}

Blackwell MI, Trudgen ME and Weston AS (1978) Vegetation and Floristics of the Burrup Peninsula. (Blackwell and Cala: Perth)

Department of the Environment, Water, Heritage and the Arts (2008) Interim Biogeographic Regionalisation for Australia (IBRA), Version 6.1 http://www.environment.gov.au/parks/nrs/ science/bioregio-framework/ibra/index.html

IUCN Standards and Petitions Subcommittee (2010) Guidelines for Using the IUCN Red List Categories and Criteria. Version 8. Prepared by the Standards and Petitions Subcommittee in March 2010. http://intranet.iucn.org/webfiles/doc/SSC/RedList/RedListGuidelines.pdf (Accessed May 2010)

Lazarides M (1997) A revision of Eragrostis (Eragrostideae, Elusininae, Poaceae) in Australia. Australian Systematic Botany 10: 77-187

Palmer J, Lazarides M, McCusker A \& Weiller CM (2005) Eragrostis. Pp. 346-348 in Mallett K (ed.) Flora of Australia 44B. (Australian Government Publishing Services: Canberra)

Smith MF (2010) Declared Rare and Priority Flora List for Western Australia. (Department of Environment and Conservation: Kensington, WA)

Trudgen ME \& Associates (2002) A Flora, Vegetation and Floristic Survey of the Burrup Peninsula, Some Adjoining areas and Part of the Dampier Archipelago, With Comparisons to the Floristics of Areas on the Adjoining Mainland. Volume 1 \& 2. (M.E. Trudgen and Associates and The Department of Mineral and Petroleum Resources, Perth)

Western Australian Herbarium (1998+) FloraBase - The Western Australian Flora. Department of Environment and Conservation. http://florabase.dec.wa.gov.au/ (Accessed 17 Feb 2010) 